\title{
Effects of physical factors on larval behavior, settlement and recruitment of four tropical demosponges
}

\author{
Manuel Maldonado*, Craig M. Young \\ Department of Larval Ecology, Harbor Branch Oceanographic Institution, 5600 US 1 North, Fort Pierce, Florida 34946, USA
}

\begin{abstract}
This study investigated the effects of light, water flow and water temperature on larvae and early juveniles of 4 shallow-water Caribbean demosponges, Tedania ignis, Haliclona tubifera, Sigmadocia caerulea and Halichondria magniconulosa. Larval release was not a synchronous event, either at the individual or population level in any of these species. Parenchymella larvae were photonegative during their whole life, but their swimming speed to escape from a light source varied with species and was related to the ratio of larval body length:flagellar tuft length. The presence of a water flow faster than the larval swimming speed had no effect on the settlement success of these 4 species in experimental flumes. Larvae of all 4 species preferred shaded sites at settlement in flumes. However, microhabitat irradiance in the field was correlated with abundances of adults only in 1 species, $S$. caerulea. The presence of water flow was positively associated with juvenile survivorship in the field only in the case of $T$. ignis. Water flow was also positively associated with the adult abundance of $T$. ignis, but negatively associated with the abundance of $H$ tubifera. Recruitment varied substantially among species, being extremely low in $H$. tubifera and H. magniconulosa. Larval activity and settlement of 2 species were strongly affected by abnormally low temperatures: swimming speed decreased, the free-swimming phase was dramatically shortened and recruitment was virtually inhibited. Low temperatures, therelore, potentially prevent larval dispersal and recruitment into cold waters and might restrict the geographic distribution of these species to tropical areas and warm shallow waters.
\end{abstract}

KEY WORDS: Parenchymella larva $\cdot$ Photoresponse - Sponge settlement - Sponge recruitment

\section{INTRODUCTION}

Parenchymella larvae of demosponges have often been studied morphologically, but little experimental work has been done on their behavior. It is a wellknown fact that sponge larvae respond behaviorally to some physical stimuli, despite the apparent absence of sensory organs or nervous integration. Light seems to be the main cue for orientation of free-swimming larvae of shallow-water sponges (Bergquist \& Sinclair 1968, Fry 1971, Wapstra \& van Soest 1987, Woollacott 1993). Many shallow-water sponge larvae are either photonegative during the whole larval life or they become

\footnotetext{
- Present address: Department of Aquatic Ecology, Centro de Estudios Avanzados de Blanes, CSIC, Camino de Santa Barbara s/n, Blanes, E-17300 Girona, Spain.

E-mail:maldonado@ceab.es
}

photonegative at settlement (Bergquist et al. 1970, Wapstra \& van Soest 1987). Among sessile invertebrates, negative phototaxis is thought to facilitate settlement in crevices and on downward-facing surfaces, where juvenile survival may be enhanced because of reduced exposure to predators, bright light, silt and other factors that covary with light (e.g. Keough \& Downes 1982, Young \& Chia 1984, Hulburt 1993).

It has been suggested that the larval response to light can be very important in determining the final spatial distribution of adult sponges (e.g. Warburton 1966, Bergquist et al. 1970, Fell 1974). However, as the swimming ability of sponge larvae is very limited, water currents and turbulence are expected to interfere with larval photoresponse. Strong currents could even eliminate the possibility of active larval selection at settlement, leading to a spatial distribution that results exclusively from hydrodynamic factors (e.g. 
Woodin 1986, Butman 1987, Pawlik 1992, Snelgrove 1994). Hydrodynamic factors have been found to be very important in determining the spatial pattern of settlement in many filter-feeders (e.g. Warner 1977 , Young \& Braithwaite 1980, Dolmer \& Svane 1993, Pawlik \& Butman 1993). Sponges are particularly abundant in habitats characterized by the presence of a steady water flow (e.g. de Laubenfels 1950, Sará \& Vacelet 1973, Wilkinson \& Vacelet 1979). Thus, water flow may play an important role in either enhancing or inhibiting settlement or recruitment, but its effects on larval behavior, settlement and recruitment of sponges have never actually been investigated.

Other major abiotic factors, such as temperature, can influence the distribution of adult organisms on larger spatial scales, since they affect physiological processes during all life-history stages. For example, temperature has been considered to explain medium- and large-scale distribution patterns in sponges (Reid 1968, Sará \& Vacelet 1973, Vacelet 1988). Seasonal and latitudinal changes in temperature are also known to affect the body sizes of adult sponges as well as the formation of silica and spongin skeletons (e.g. Hentschel 1929, Hartman 1958, Bergquist \& Sinclair 1973, Simpson 1978, Bavastrello et al. 1993). However, the larval tolerances and behavioral responses to temperature changes remain virtually unexplored in sponges.

This study explores the role of light, water flow and water temperature on larval behavior, settlement and recruitment of 4 tropical, shallow-water demosponges.

\section{MATERIAL AND METHODS}

Habitat characteristics. We studied 4 demosponge species, Tedania ignis (Duchassaing \& Michelotti), Halichondria magniconulosa Hechtel, Haliclona tubifera (George \& Wilson) and Sigmadocia caerulea Hetchel. They all brood embryos and release parenchymella larvae, and all have a biogeographical distribution limited to tropical, shallow waters. These 4 species are common in a sponge-dominated community established on boulders and cobbles between 0.5 and $2 \mathrm{~m}$ deep in the Indian River Lagoon, near the Fort Pierce Inlet, Florida. During about half of the daylight hours, part of this community is shaded by a manmade pier. The community is also influenced by tidal currents flowing through nearby Fort Pierce Inlet. There is an onshore-offshore gradient in water flow. That portion of the community at the outer portion of the study area is subjected to currents of 10 to $50 \mathrm{~cm} \mathrm{~s}^{-1}$. The inner half of the community (near shore) is affected by weaker currents $\left(<5 \mathrm{~cm} \mathrm{~s}^{-1}\right)$ and is generally characterized by still water. Because of the interaction between currents and light conditions, we predicted the existence of 4 major microhabitats in this community (Fig. 1): (1) sites with high exposure to water movement and light; (2) sites with high exposure to water movement but low exposure to light; (3) sites with reduced water movement but high exposure to light; and (4) sites with reduced exposure to water movement and light.

In order to quantify differences in irradiance and water flow, these variables were measured at 5 sites within each of the 4 major microhabitats. Light irradiance (photons $\mathrm{s}^{-1} \mathrm{~m}^{-2}$ ) was measured by using a LI1000 Data Logger with a LI-192SA underwater quantum sensor. Mean daily irradiance at each site was obtained by averaging 4 measurements recorded at different times during daylight hours $(10: 30,1230$, $14: 30$ and $16: 30 \mathrm{~h}$ ) on a cloudy and a sunny day. Net flow was measured at each site by recording weight loss of small cylinders of plaster of Paris after $24 \mathrm{~h}$. This method is based on the assumption that more water movement results in a higher dissolution rate of plaster of Paris, irrespective of the direction of flow, the maximum velocity, or the fluctuation in velocity (Denny 1988). A discriminant analysis on standardized data was used to test for the existence of site groups on the basis of these light and hydrodynamic characteristics and to evaluate the goodness of fit between observed and predicted groups (Ludwig \& Reynolds 1988).

Adult abundance. Adult abundance of each species in each microhabitat was estimated by counting the number of individuals contained in nine $150 \times 50 \mathrm{~cm}$ quadrats placed at random. Population censuses were made during November 1994, after the reproductive season was over and individuals from the most recent cohort of recruits were large enough to be seen underwater. Differences in the numbers of individuals among microhabitats were tested by 2-way ANOVA (Sokal \& Rohlf 1981), where light and water flow were factors

Reproductive timing and larval release. The density of brooded larvae per adult (mean \pm SD) was estimated

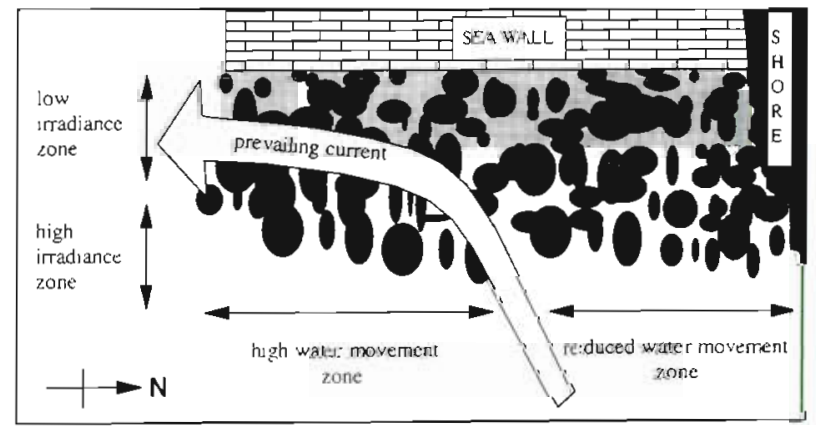

Fig. 1. Schematic diagram of the studied site, showing relationship between shaded and sunny areas and the prevailing flow 
for 3 of the 4 species by counting the embryos or larvae contained in $50 \mathrm{~mm}^{2} \times 1 \mathrm{~mm}$ slices of the choanosome. The samples were taken from 15 individuals per species biweekly, from March to September in 1994. Preliminary observations revealed that embryos are more or less evenly distributed throughout the whole choanosome, except in Sigmadocia caerulea. In this species, which is erect and branched, embryos are incubated 1 to $2 \mathrm{~mm}$ beneath the pynacothelium of the main exhalant channel of the branches. Given the nonuniform location of embryos in $S$. caerulea, this species was not considered in this part of the study, since the process of counting embryos would involve the destruction of specimens and significant population damage.

Larval morphology and behavior. In Haliclona tubifera and Halichondria magniconulosa, larval release was induced in the laboratory by light shock after dark adaptation of ripe individuals for 12 to $20 \mathrm{~h}$. In Sigmadocia caerulea, larvae were released spontaneously immediately after collection of ripe adults. It was also triggered in the laboratory by exposing ripe adults to air for several seconds. Release could not be artificially induced in Tedania ignis. Nevertheless, larvae were sometimes spontaneously released by ripe individuals after 1 to several days in aquaria.

In order to observe larval behavior, length of the swimming period, settlement and early survivorship under a standardized set of laboratory conditions, 100 larvae per species, in batches of 5 to 10 larvae, were placed in glass dishes containing 30 to $100 \mathrm{ml}$ of $0.45 \mu \mathrm{m}$ millipore filtered sea water. These containers were maintained at room temperature $\left(20-24^{\circ} \mathrm{C}\right)$ and monitored for $8 \mathrm{~d}$.

Larval swimming speed was estimated by timing the movement of 2 to $4 \mathrm{~h}$ old larvae $(\mathrm{n}=30)$ down the long axis of a plexiglas aquarium 3 deep $\times 2$ wide $\times 72 \mathrm{~cm}$ long while they were responding to light. The light source was a 150 watt, cold fiber optic light passing through a neutral density plastic diffuser.

Effects of light and water flow on settlement and recruitment. To estimate recruitment in the different microhabitats of the community, we randomly deployed a total of ten $15 \times 15 \mathrm{~cm}$ ceramic floor tiles per microhabitat. Tiles were immersed at the beginning of the seasonal peak of larval release (June 9) and checked for recruitment after 35 and $96 \mathrm{~d}$. Differences in the number of recruits among microhabitats were analyzed by 2 -way ANOVA, where light and water flow were factors.

The effect of current on larval choice at settlement in different light regimens was investigated in the laboratory with small circular flumes. The flumes consisted of circular glass channels 2 wide $\times 3 \mathrm{~cm}$ deep containing sea water. Water temperature and salinity ranged from
20 to $24^{\circ} \mathrm{C}$ and from 33 to $35 \%$ respectively during the experiments. A fluorescent lamp provided with two $15 \mathrm{w}$, cool white bulbs, was placed $25 \mathrm{~cm}$ above the channels. Light was diffused through a translucent plastic diffuser to minimize reflections by glass walls. Half of each channel was shaded by covering walls, bottom and top with an opaque black plastic. A circular water flow was created by pumping air on the water surface through 2 air jets placed at opposite sides of the channels (see Young \& Braightwaite 1980). The mean speed in the center of the channel was $3 \mathrm{~cm} \mathrm{~s}^{-1}$. By using larvae whose ciliary activity was arrested with $2 \%$ nickel sulfate, we confirmed that the shear stress created at this speed was strong enough to roll larvae along the bottom of the flumes. Additional halfshaded channels with no current served as controls. We did 2 simultaneous runs of the experiment with each species, where every run consisted of a treatment channel and a control channel, each containing 20 larvae. After $190 \mathrm{~h}$, we recorded the number of surviving settlers and their distribution with regard to light conditions. Data from 2 homogeneous runs of the experiment (homogeneity tests, Sokal \& Rohlf 1981) were pooled and arranged in $2 \times 2$ contingency tables, where the marginal totals of the variable presence/ absence of flow were fixed by the experimental design at 40 larvae. Contingency tables were analyzed by the chi-squared test of independence and association was expressed by the phi coefficient (Hays 1963). When association between light and hydrodynamic conditions did not have any effect on the distribution of settlers, we examined the main effects of these variables by a chi-squared test of goodness of fit adjusted for continuity (Sokal \& Rohlf 1981), where the ratio of expected values in the 2 levels of a variable was 50:50.

Temperature effects on larval behavior and settlement. The effect of water temperature on larvae of Haliclona tubifera and Halichondria magniconulosa was investigated by placing larvae in $30 \mathrm{ml}$ plexiglas Petri-dishes in dark incubators at $10,15,20$ and $25^{\circ} \mathrm{C}$. Treatments were applied to batches of 5 larvae per container, up to a total of 5 containers per temperature and the percentages of swimming, settled and dead larvae were recorded over time.

\section{RESULTS}

\section{Habitat characteristics}

A discriminant analysis revealed that irradiance and water flow features of the 20 studied sampling sites allowed us to cluster them in 4 groups that show significant differences among the positions of their centroids (Wilk's lambda $=0.024, F_{6,30}=27.080, \mathrm{p}<0.001$; 
Fig. 2). These groups correspond to 4 different community microhabitats, as predicted in Fig. 1. The magnitude of the canonical correlation coefficients $\left(\mathrm{R}^{2}\right.$ light $=$ $0.947, R_{\text {flow }}^{2}=0.874$ ) indicate that light is a better discriminant factor than flow; that is, irradiance differences among microhabitats are slightly stronger than water flow differences.

\section{Adult abundance}

A total of 238 adult Tedania ignis, 150 Sigmadocia caerulea, 128 Haliclona tubifera and 24 Halichondria magniconulosa were found in the 36 quadrats. The mean densities $( \pm \mathrm{SD})$ were $8.8 \pm 6.6,5.7 \pm 5.5,4.7 \pm 6.2$ and $0.8 \pm 1.6$ individuals $\mathrm{m}^{-2}$, respectively. Analyses of the abundances of adult sponges in the 4 natural microhabitats revealed no significant interaction between light and current conditions (Table 1, Fig. 3). Light by itself had no effect on the distribution of adults of any species, except $S$. caerulea. However, the presence of water flow did influence 2 species, $T$. ignis and H. tubifera. Flow was positively associated with the abundance of $T$. ignis $(F=25.953, \mathrm{p}<0.001)$ and negatively associated with the abundance of $H$. tubifera $(F=$ 42.771, $p<0.001)$. This effect was particularly strong for $H$. tubifera, which was virtually absent from the microhabitats with high currents. The distribution of

Table 1 Two-way analysis of variance on the effect of flow and light on the abundance of adult sponges in the 4 major community microhabitats

\begin{tabular}{|lrrrr|}
\hline Source & df & \multicolumn{1}{c}{ MS } & \multicolumn{1}{c|}{$F$} & \multicolumn{1}{c|}{ p } \\
\hline Tedania ignis & & & & \\
Flow & 1 & 386.778 & 25.953 & $<0.001$ \\
Light & 1 & 11.111 & 0.746 & 0.394 \\
Flow $\times$ Light & 1 & 1.778 & 0.119 & 0.732 \\
Error & 32 & 14.903 & & \\
Haliclona tubifera & & & & \\
Flow & 1 & 427.111 & 42.771 & $<0.001$ \\
Light & 1 & 7.111 & 0.712 & 0.405 \\
Flow $\times$ Light & 1 & 7.111 & 0.712 & 0.405 \\
Error & 32 & 9.986 & & \\
Halichondria magniconulosa & & & \\
Flow & 1 & 0.444 & 0.275 & 0.604 \\
Light & 1 & 0.000 & 0.000 & 1.000 \\
Flow $\times$ Light & 1 & 1.788 & 1.099 & 0.302 \\
Error & 32 & 1.618 & & \\
Sigmadocia caerulea & & & & \\
Flow & 1 & 30.028 & 2.593 & 0.117 \\
Light & 1 & 90.250 & 6.153 & $<0.019$ \\
Flow $\times$ Light & 1 & 0.028 & 0.002 & 0.966 \\
Error & 32 & 14.667 & & \\
\hline & & & & \\
\hline
\end{tabular}

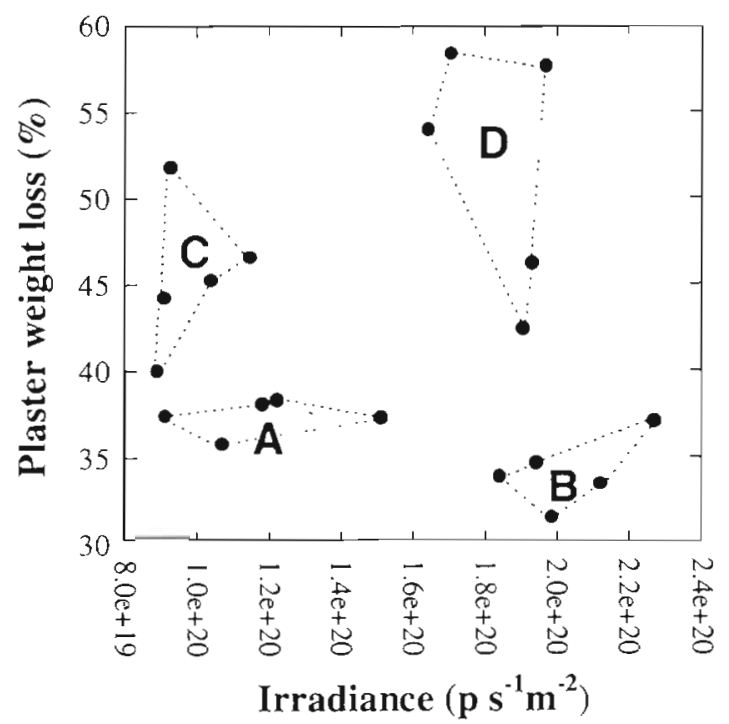

Fig. 2. Community sites clustered according to their irradiance and hydrodynamic characteristics. Water movement was measured with plaster of Paris cylinders. The statistical significance of the resulting groups was tested by discriminant analysis

H. magniconulosa did not seem to be affected by either hydrodynamics or light conditions (Table 1). The relatively small number of individuals of this species could be responsible for the observed lack of statistical significance.

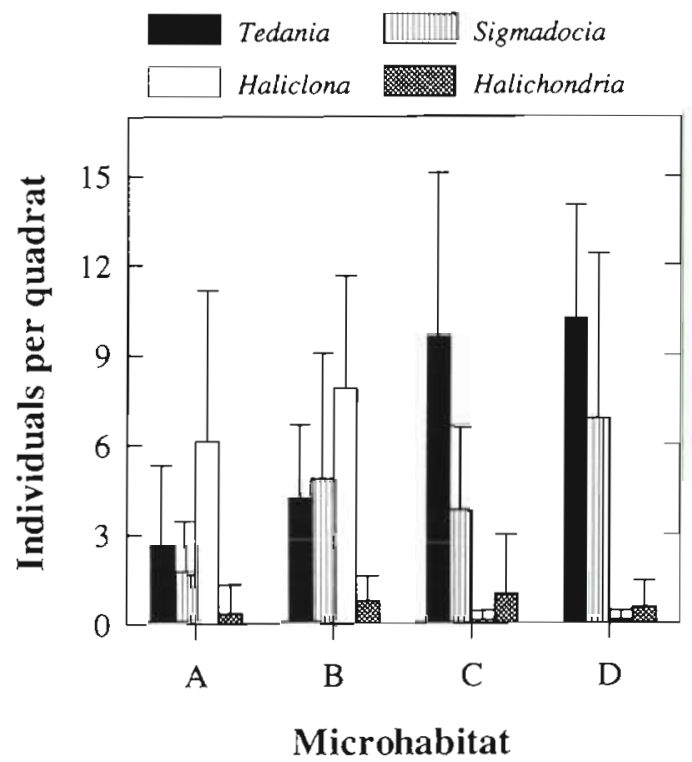

Fig. 3. Mean number of adult sponges per sampling quadrat in the major community microhabitats. Error bars are standard deviation. A: sites with low irradiance and reduced water movement; B: sites with high irradiance and reduced water movement; $C$ : sites with low irradiance and high water movement; $\mathrm{D}$ : sites with high irradiance and high water movement 


\section{Reproductive timing and larval release}

The larval release season of Tedania ignis, Haliclona tubifera and Halichondria magniconulosa started in late April, during a period of rise in water temperature (Fig. 4a). At the beginning of the reproductive season, embryos were found in 90 to $100 \%$ of the individuals. Although we did not search for male gametes, this high percentage of brooding individuals suggests that all 4 species are hermaphroditic. Densities of eggs and/or embryos were highest at the beginning of the reproductive period (Fig. 4a). The number of eggs/embryos in $0.5 \mathrm{~cm}^{2} \times 0.1 \mathrm{~cm}$ sections of tissue was $10.6 \pm 2.7$ in $T$. ignis, $22.8 \pm 5.1$ in $H$. tubifera and $27.8 \pm 5.5$ in $H$. magniconulosa. In $H$. tubifera and $H$. magniconulosa, larval release ceased by mid July, whereas it lasted until late August in T. ignis. The gradual decrease of the mean number of eggs/embryos per individual over time (Fig. 4a), as well as the high standard deviation of these values from May to June (Fig. 4b), suggests that larval release in these 3 species is a relatively long and asynchronous process at the population level. Variation over time in the number of larvae contained by adults, as represented by the coefficient of variation, indicates that the dynamics of the larval release are similar in $H$. tubifera and $H$. magniconulosa (Fig. 4c). Greater asynchrony occurred in $T$ ignis, especially at the end of the season. Sigmadocia caerulea released larvae from June until September, with a peak in August and September.

In Haliclona tubifera, Halichondria magniconulosa and Sigmadocia caerulea, larvae were expelled through oscula shortly after adults were illuminated and for 1 to $2 \mathrm{~h}$ thereafter. In Tedania ignis, larvae emerged through the ectosome, probably through the ostioles. $H$. tubifera and $H$. magniconulosa individuals required at least 3 massive releases, usually on successive days, to expel their entire brood of larvae. After each of the first 2 release events, the total number of larvae remaining in the adults decreased to about $50 \%$ of the original number. After a third release, most adults were virtually empty of larvae. Massive releases on consecutive days were never observed in $T$ ignis, but small numbers (15 to 50) of larvae were released by adults several days before and after a massive release. It appeared that ripe individuals of $T$. ignis need at least 1 massive release along with multiple small ones to expel the entire brood

\section{Larval morphology and behavior}

Parenchymella larvae of all 4 species are elongate spheroids, whitish in Sigmadocia caerulea, red-orange in Tedania ignis, whitish pink in Haliclona tubifera and

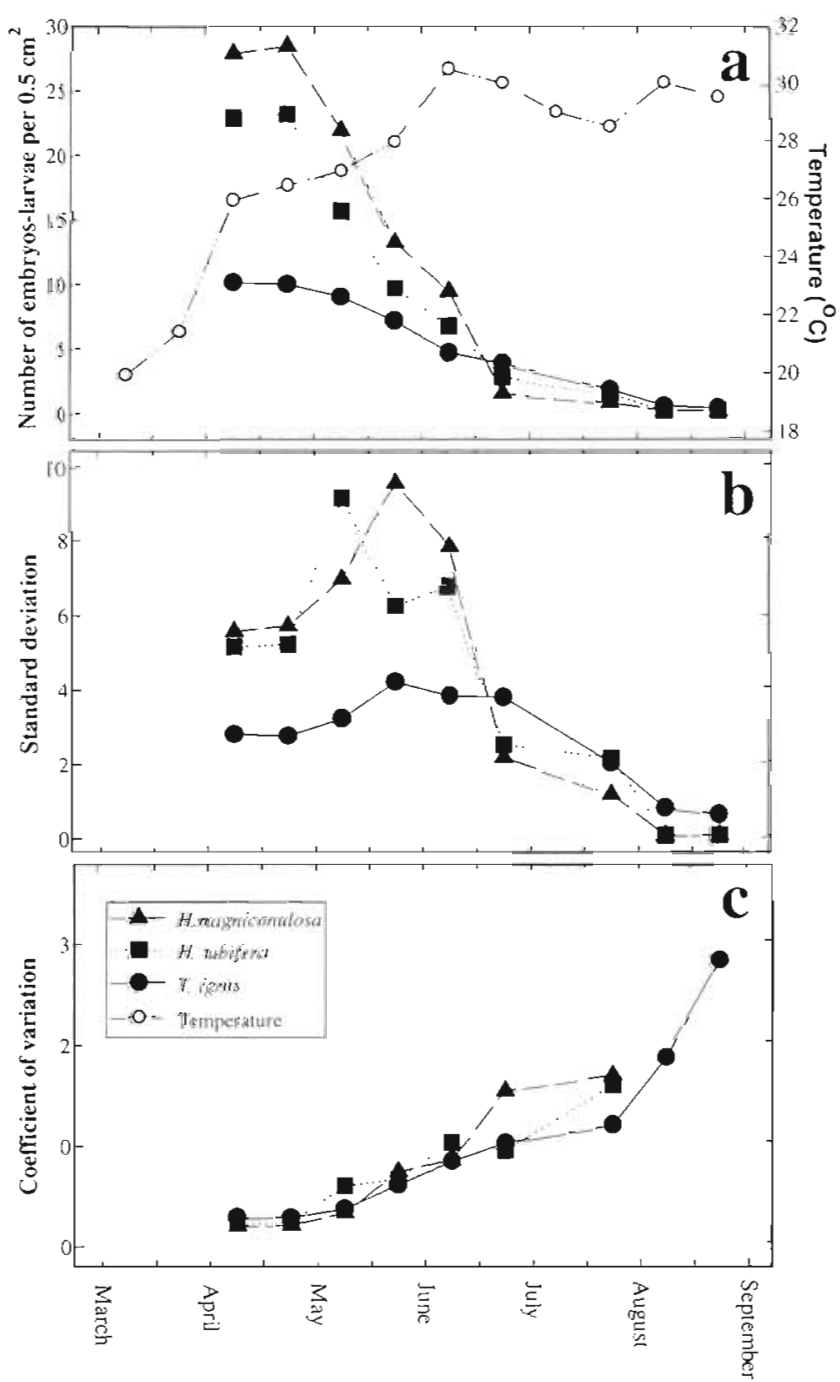

Fig. 4. Reproduction as a function of season: (a) water temperature and mean number of embryos or larvae $0.5 \mathrm{~cm}^{-2}$ over time, (b) standard deviation of the mean number of embryos or larvae $0.5 \mathrm{~cm}^{-2}$ over time, (c) coefficient of variation of the number of embryos or larvae over time

yellow in Halichondria magniconulosa. They are uniformly covered with short cilia, except for the posterior end which is bare. This posterior end is surrounded by a ring of flagellated cells forming a distinctive tuft in $S$. caerulea, $H$. tubifera and $H$. magniconulosa, but the posterior ring of flagella is the same length as the rest of the ciliature in $T$. ignis. The mean length $( \pm \mathrm{SD})$ of the flagellar tuft is $15 \pm 3 \mu \mathrm{m}$ in T. ignis, $30 \pm 3 \mu \mathrm{m}$ in $H$. magniconulosa, $50 \pm 4 \mu \mathrm{m}$ in $H$. tubifera and $80 \pm 5 \mu \mathrm{m}$ in $S$. caerulea.

Larvae can temporarily constrict the middle of their bodies, as well as extrude and protract the anterior ends. Larvae of Halichondria magniconulosa are capable of remarkable shape changes over relatively short times. In general, 2 to $3 \mathrm{~h}$ old larvae are oval, with 
length: width ratios between 1.5 and 2 , whereas 10 to $12 \mathrm{~h}$ old larvae become somewhat flatter and longer (length: width ratio $=2.5$ ). The mean length in this species was $318 \pm 45.3 \mu \mathrm{m}$ for larvae younger than $6 \mathrm{~h}$ and $468 \pm 67.3 \mu \mathrm{m}$ for larvae older than $12 \mathrm{~h}$. Haliclona tubifera, Sigmadocia caerulea, and Tedania ignis larvae measured $425 \pm 79.68,629.2 \pm 95.8$ and $758.7 \pm$ $110.64 \mu \mathrm{m}$, respectively, with constant length:width ratios over time.

Larvae of all 4 species swim with a clockwise corkscrew motion and with the flagellar end directed backwards, but there are interspecific differences in swimming behavior. Larvae of Haliclona tubifera, Sigmadocia caerulea, and Halichondria magniconulosa swim actively near the water surface for 6 to $12 \mathrm{~h}$ after release. Then, swimming speed gradually decreases and larvae exhibit an 'exploratory' behavior, moving closely to the bottom of containers where they remain for between a few minutes and $90 \mathrm{~h}$. By contrast, Tedania ignis larvae never swim vigorously; they remain near the bottom unless disturbed by water turbulence.

Settlement occurs in different ways, depending upon the species. Larvae of Haliclona tubifera and Sigmadocia caerulea position themselves perpendicular to the bottom, with the anterior pole oriented toward the substratum, and they spin with a clockwise rotation for between a few minutes and up to $3 \mathrm{~h}$. While rotating, threads of a transparent solid substance (basal spongin?) are released around the future settlement spot. Spinning stops prior to settlement, and larvae always attach by the anterior end. The flagellar tuft beats for between 15 and 40 min after settlement, and then is shed. In Halichondria magniconulosa, there is no spinning phase. The corkscrew swimming movement ceases and the flattened larvae crawl on the bottom by one of their lateral sides for between a few minutes and $4 \mathrm{~h}$. Larvae may attach either by the anterior end or one lateral side. About $40 \%$ of the time, attachment is by a lateral side. The whole flagellar tuft is instantaneously expelled just before settlement. Larvae of Tedania ignis stop corkscrew swimming after 12 to $72 \mathrm{~h}$, crawl for a variable period of time and finally attach by the anterior pole. Fusion of larvae and early juveniles was common in $T$. ignis, $S$. caerulea and $H$. tubifera, especially when larvae were high in density in the containers. A single osculum appeared in juveniles of all 4 species about $2 \mathrm{~d}$ after settlement.

There was approximately $50 \%$ mortality of Haliclona tubifera and Halichondria magniconulosa after $8 \mathrm{~d}$ in the laboratory dishes. More in vitro mortality occurred in juveniles than in swimming larvae. Juveniles were especially vulnerable to mortality 24 to $48 \mathrm{~h}$ after settlement, and prior to the formation of any oscular finger. Survival of Tedania ignis and Sigmadocia caerulea was clearly higher than those of the other 2 species (Fig. 5).
It is noteworthy that $T$ ignis larvae that did not settle within about $96 \mathrm{~h}$ lost body ciliation and became lethargic. Nevertheless, most of these lethargic larvae were able to attach about 2 d later, and they ultimately became healthy juveniles. We also found that $H$. tubifera larvae that swam for at least $72 \mathrm{~h}$ were able to settle successfully. These observations are contrary to the observations reported by Woollacott (1993) indicating that larvae of this species that do not settle within $24 \mathrm{~h}$ die before an additional $8 \mathrm{~h}$ passed. Juveniles from larvae that had delayed settlement showed a shortterm mortality (after $4 \mathrm{~d}$ ) similar to that of juveniles from. larvae swimming for less than $72 \mathrm{~h}$.

\section{Effects of light and water flow on settlement and recruitment}

Larvae of all 4 species were photonegative during the whole swimming period in laboratory conditions. Response to light, as measured by larval swimming speed in response to lateral illumination, was different in each species. Mean swimiming speed $( \pm$ SD) was $0.36 \pm 0.05 \mathrm{~cm} \mathrm{~s}^{-1}$ in Sigmadocia caerulea, $0.27 \pm$ $0.04 \mathrm{~cm} \mathrm{~s}^{-1}$ in Haliclona tubifera, $0.17 \pm 0.07 \mathrm{~cm} \mathrm{~s}^{-1}$ in Halichondria magniconulosa and $0.098 \pm 0.06 \mathrm{~cm} \mathrm{~s}^{-1}$ in Tedania ignis. Our results, along with larval measurements reported for Halichondria melanodocia (Woollacott 1990), indicate that the capacity to swim in response to light is related to the ratio of flagellar tuft length: body length $\left(r^{2}=0.859, n=5, p=0.024\right.$; Fig. 6) .

Larvae placed in the flume initially demonstrated a positive rheotaxis. They initially faced into the current, but were unable to swim against it because the mean

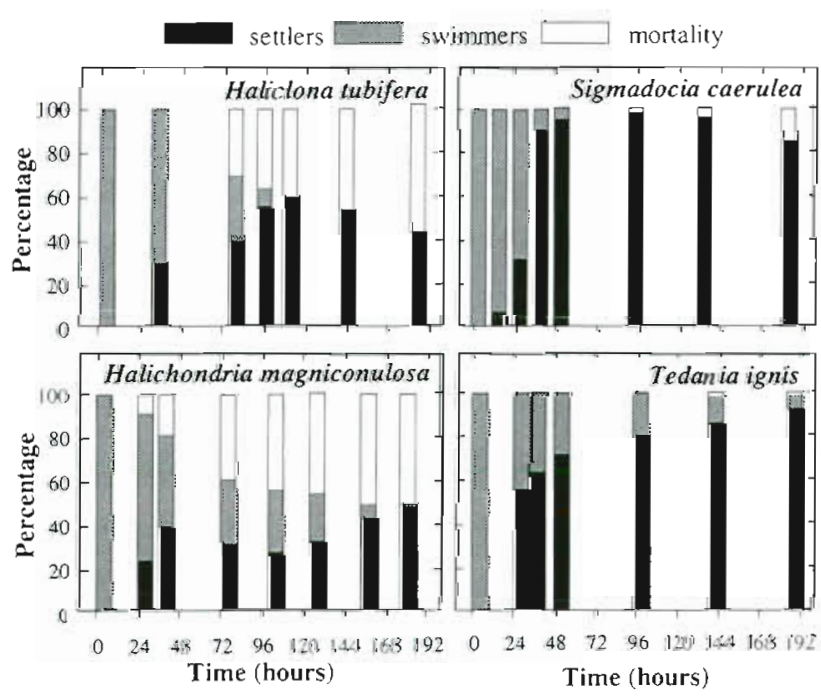

Fig. 5. Cumulative percentages of free-swimming larvae, settlers and mortality in laboratory dishes over tume 


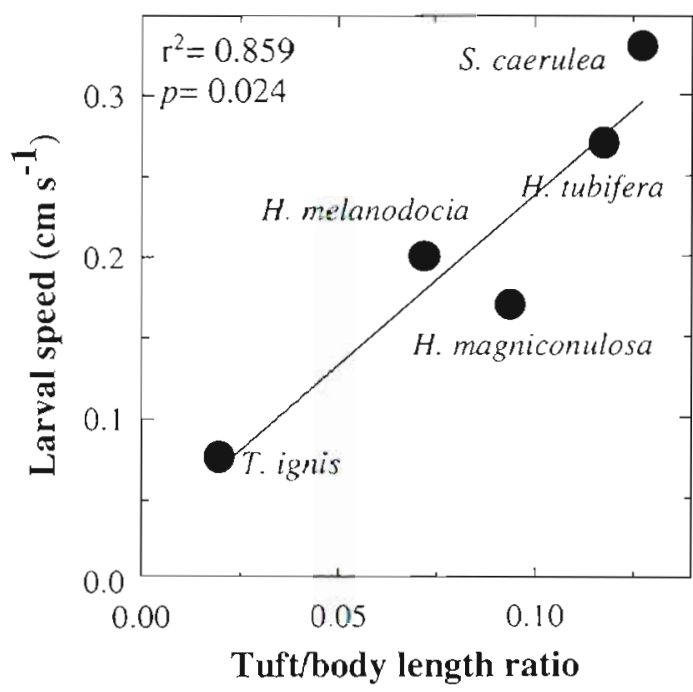

Fig. 6. Linear regression showing the relationship between tuft:body length ratio and larval swimming speed while exhibiting a photonegative response

Table 2. Row by column tests of independence between success/failure at settlement and presence/absence of current in circular aquaria. $\chi_{Y}^{2}$ : Yates-corrected chi-squared; + : presence of current; - absence of current

\begin{tabular}{|c|c|c|c|c|c|c|c|c|}
\hline & \multicolumn{2}{|c|}{$\begin{array}{l}\text { Tedania } \\
\text { ignis }\end{array}$} & \multicolumn{2}{|c|}{$\begin{array}{c}\text { Sigmadocia } \\
\text { caerulea }\end{array}$} & \multicolumn{2}{|c|}{$\begin{array}{c}\text { Haliclona } \\
\text { tubifera }\end{array}$} & \multicolumn{2}{|c|}{$\begin{array}{l}\text { Halichondria } \\
\text { magniconulosa }\end{array}$} \\
\hline & \multicolumn{2}{|c|}{ Current } & \multicolumn{2}{|c|}{ Current } & \multicolumn{2}{|c|}{ Current } & \multicolumn{2}{|c|}{ Current } \\
\hline & + & - & + & - & + & - & + & - \\
\hline Alive & 40 & 39 & 26 & 28 & 38 & 37 & 26 & 28 \\
\hline Dead & 0 & 1 & 14 & 12 & 2 & 3 & 14 & 12 \\
\hline & \multicolumn{2}{|c|}{$\begin{aligned} x_{Y}^{2} & =0.000 \\
p & =1\end{aligned}$} & \multicolumn{2}{|c|}{$\begin{aligned} x^{2} & =0.228 \\
p & =0.633\end{aligned}$} & \multicolumn{2}{|c|}{$\begin{aligned} \chi_{y}^{2} & <0.001 \\
p & =1\end{aligned}$} & \multicolumn{2}{|c|}{$\begin{aligned} \chi^{2} & =0.228 \\
p & =0.633\end{aligned}$} \\
\hline
\end{tabular}

flow speed $\left(3 \mathrm{~cm} \mathrm{~s}^{-1}\right)$ was much higher than the larval swimming speed. The presence of the flow did not affect settlement success in any of the 4 species (Table 2). Larvae of Sigmadocia caerulea, Haliclona tubifera and Halichondria magniconulosa significantly preferred shaded sites $\left(\chi^{2}\right.$ adj $=9.292, \mathrm{p}$ $<0.005 ; \chi_{\text {adj }}^{2}=21.33, \mathrm{p}<0.001 ;$ and $\chi^{2}{ }_{\mathrm{dd} d}=5.35, \mathrm{p}<$ 0.025 , respectively), but this choice was made independently of the presence or absence of current (Table 3). Flow increased the chance that Tedania ignis larvae would settle in shaded sites.

The recruitment of sponges on ceramic tiles placed in the field varied substantially among species. After 35 d, we recorded 258 recruits of Tedania ignis and 30 of Sigmadocia caerulea on the tiles, but only 1 recruit for each of Haliclona tubifera and Halichondria magniconulosa. The recruit- ment of sponges and most other invertebrates occurred mainly on the undersurfaces of the tiles, regardless of which location in the major community microhabitats the tiles were placed in. The exposed surface was always fully covered by fine sediment and usually by green filamentous algae as well.

The distribution of the recruits of Tedania ignis after $35 d$ was significantly higher in the shaded parts of the community (Fig. 7. Table 4), irrespective of flow conditions. The abundance of small recruits and the scarcity of large recruits suggests that there is high mortality within a few days of settlement. After $96 \mathrm{~d}$, the number of surviving recruits of $T$. ignis had decreased in all microhabitats, except the one characterzed by high water movement and high irradiance (Fig 7). Recruitment after $96 \mathrm{~d}$, unlike that after $35 \mathrm{~d}$, was not affected by light differences among microhabitats, but it was influenced by water movement (Table 4). At this time, juvenile survivorship for $T$. ignis was significantly higher in all sites with high water movement, irrespective of light conditions. Recruitment of Sigmadocia caerulea after 35 and 96 d was not affected by either light or hydrodynamic conditions of microhabitats (Table 4). The number of survivors did not substantially vary between 35 and $96 \mathrm{~d}$. Haliciona tubifera and Halichondria magniconulosa had low numbers of recruits after 35 and $96 \mathrm{~d}$.

\section{Temperature effects on larval behavior and settlement}

The larval release season of Haliclona rubifera and Halichondria magniconulosa begins in late April, during a period when water temperature is rising (Fig. 4a). Larval release under natural conditions occurs at temperatures between 25 and $31^{\circ} \mathrm{C}$. Experimental results

Table 3. Row by column tests of association between experimental conditions of light and current as cues used by sporge larvae at settlement. $\chi_{\gamma}^{2}$ : Yates-corrected chi-squared $;$; presence of factor; -: absence of factor; $\varphi$ : phi coefficient of contingency

\begin{tabular}{|c|c|c|c|c|c|c|c|c|}
\hline & \multicolumn{2}{|c|}{$\begin{array}{l}\text { Tedania } \\
\text { ignis }\end{array}$} & \multicolumn{2}{|c|}{$\begin{array}{c}\text { Sigmadoria } \\
\text { caerulea }\end{array}$} & \multicolumn{2}{|c|}{$\begin{array}{c}\text { Halichlona } \\
\text { tubifera }\end{array}$} & \multicolumn{2}{|c|}{$\begin{array}{l}\text { Halichondria } \\
\text { magniconulosa }\end{array}$} \\
\hline & \multicolumn{2}{|c|}{ Current } & \multicolumn{2}{|c|}{ Current } & \multicolumn{2}{|c|}{ Current } & \multicolumn{2}{|c|}{ Current } \\
\hline & + & - & + & - & + & - & + & - \\
\hline $\begin{array}{r}+ \\
\text { Light }\end{array}$ & $\begin{array}{l}11 \\
29\end{array}$ & $\begin{array}{l}20 \\
19\end{array}$ & $\begin{array}{c}5 \\
21\end{array}$ & $\begin{array}{l}10 \\
18\end{array}$ & $\begin{array}{l}11 \\
27\end{array}$ & $\begin{array}{c}6 \\
31\end{array}$ & $\begin{array}{l}7 \\
19\end{array}$ & $\begin{array}{l}11 \\
17\end{array}$ \\
\hline Statistics & $\begin{aligned} x_{y}^{2} & = \\
p & = \\
\varphi & =\end{aligned}$ & $\begin{array}{l}.684 \\
.030 \\
0.244\end{array}$ & $\begin{array}{r}x^{2}= \\
p=\end{array}$ & $\begin{array}{l}.826 \\
.177\end{array}$ & $\begin{array}{c}\chi_{Y y}^{2}= \\
p=\end{array}$ & $\begin{array}{l}1.733 \\
0.188\end{array}$ & $\begin{array}{l}x^{2}= \\
p=\end{array}$ & $\begin{array}{l}0.927 \\
0.336\end{array}$ \\
\hline
\end{tabular}




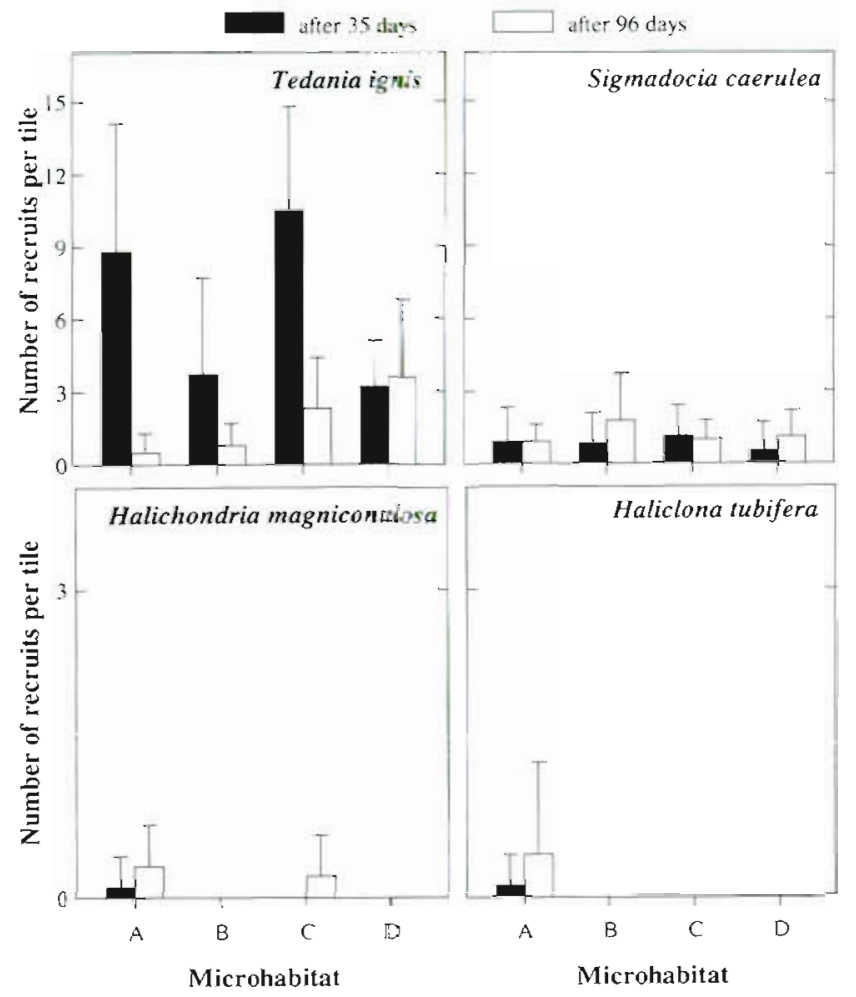

Fig. 7 Mean number of recruits per tile in the major community microhabitats after 35 and $96 \mathrm{~d}$. Error bars are standard deviation. A: sites with low irradiance and reduced water movement; $B$ : sites with high irradiance and reduced water movement; $C$ : sites with low irradiance and high water movement; $D$ : sites with high irradiance and high water movement

indicated that water temperature is very important in controlling the length of the free-swimming period of $H$. tubifera and $H$. magniconulosa larvae (Figs. 8 \& 9). At 10 and $15^{\circ} \mathrm{C}$, the swimming phase was reduced and larvae settled in less than $24 \mathrm{~h}$. However, juvenile mortality was high (close or equal to $100 \%$ ) after $2 \mathrm{~d}$, since attached larvae apparently could not complete metamorphosis. Those larvae that were unattached after $24 \mathrm{~h}$ at $15^{\circ} \mathrm{C}$ became lethargic, demonstrating some ciliary activity but no swimming capability. Approximately $20 \%$ of these lethargic larvae resumed swimming and were able to complete metamorphosis when they were transferred into warmer water after less than $12 \mathrm{~h}$ exposure to low temperatures. It is noteworthy that low temperatures induced a major shape change in larvae of $H$. magniconulosa. The body lengthened to between 50 and $100 \%$ of the original length when exposed to temperatures of 10 and $15^{\circ} \mathrm{C}$

At 20 and $25^{\circ} \mathrm{C}$, the swimming phase lasted longer in both species and settlement was enhanced. Survival after $170 \mathrm{~h}$ was much higher in Haliclona tubifera than in Halichondria magniconulosa (Figs. 8 \& 9). The mortality patterns in $H$. tubifera were similar at both tem-
Table 4. Tedania ignis and Sigmadocia caerulea. Two-way analyses of variance on the effect of flow and light on recruitment (after 35 and 96 d) to ceramic tiles placed in the 4 major microhabitats

\begin{tabular}{|c|c|c|c|c|}
\hline Source & $\mathrm{df}$ & MS & $F$ & $\mathrm{p}$ \\
\hline \multicolumn{5}{|c|}{$T$ ignis after $35 \mathrm{~d}$} \\
\hline Flow & 1 & 3.600 & 0.210 & 0.649 \\
\hline Light & 1 & 384.400 & 22.472 & $<0.001$ \\
\hline Flow $\times$ Light & 1 & 12.100 & 0.707 & 0.406 \\
\hline Error & 36 & 17.106 & & \\
\hline \multicolumn{5}{|c|}{ T. Ignis after $96 \mathrm{~d}$} \\
\hline Flow & 1 & 52.900 & 12.645 & 0.001 \\
\hline Light & 1 & 6.400 & 1.530 & 0.224 \\
\hline Flow $\times$ Light & 1 & 2.500 & 0.598 & 0.406 \\
\hline Error & 36 & 4.183 & & \\
\hline \multicolumn{5}{|c|}{ S. caerulea after $35 \mathrm{~d}$} \\
\hline Flow & 1 & 0.025 & 0.014 & 0.908 \\
\hline Light & 1 & 12.2 .5 & 0.669 & 0.419 \\
\hline Flow $\times$ Light & 1 & 0.625 & 0.341 & 0.563 \\
\hline Error & 36 & 1.831 & & \\
\hline \multicolumn{5}{|c|}{ S. caerulea after $96 \mathrm{~d}$} \\
\hline Flow & 1 & 0.900 & 0.585 & 0.449 \\
\hline Light & 1 & 2.500 & 1.625 & 0.221 \\
\hline Flow $\times$ Light & 1 & 1.600 & 1.040 & 0.315 \\
\hline Error & 36 & 1.539 & & \\
\hline
\end{tabular}

peratures, whereas they were notably different in $H$. magniconulosa. Nevertheless, the final percentage of mortality in this latter species was similarly high at both temperatures after $170 \mathrm{~h}$.

\section{DISCUSSION}

\section{Reproductive timing}

In all 4 species of sponges, larval release extends over a long period of time, and it is not a synchronous event at either the individual or population level. Asynchrony in larval release has also been reported in other viviparous species inhabiting both tropical and subtropical areas (Reiswig 1973. Hoppe 1988, Ilan \& Loya 1988,1990$)$ and also in regions with marked seasons (Fell 1974. Wapstra \& van Soest 1987). This asynchrony in larval release, both at the population and the individual level, probably reflects an asynchrony of gametogenesis in viviparous sponges (Ilan \& Loya 1988, Witte et al. 1994). Oviparous species, on the other hand, have been reported to have a very precise synchrony in gametogenesis and spawning both at the individual and population level (Sará 1961, Siribelli 1962, Reiswig 1970, 1976, Hoppe \& Reichert 1987, Fromont 1988, Fromont \& Bergquist 1994). Asynchrony in gametogenesis in viviparous species probably leads 


\section{Haliclona tubifera}

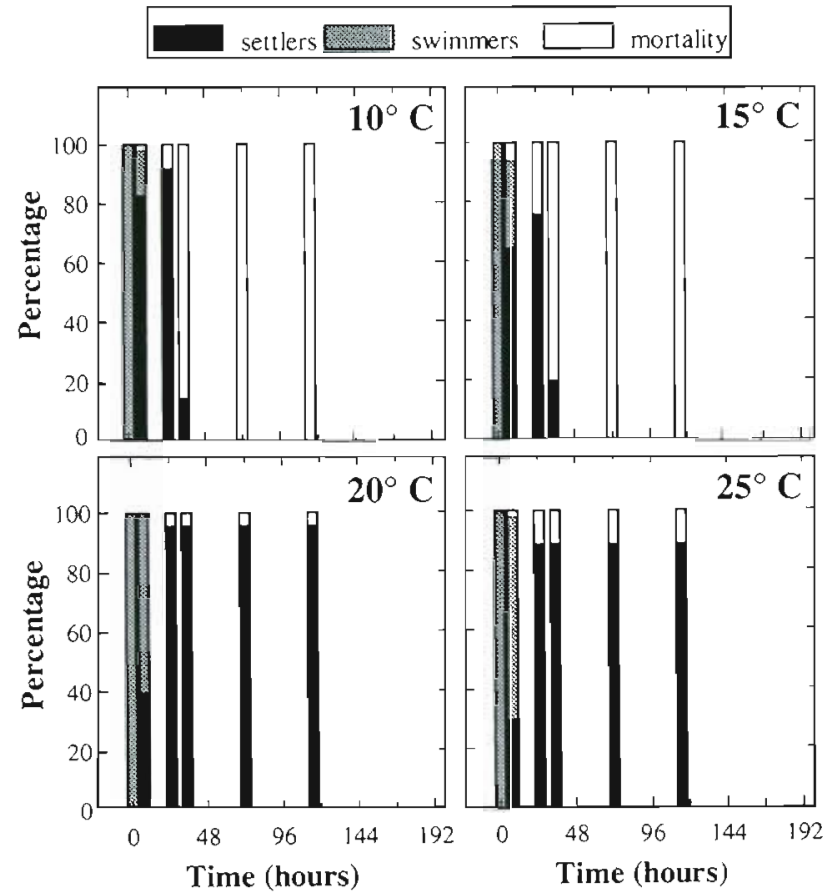

Fig. 8. Haliclona tubifera. Cumulative percentages of freeswimming larvae, settlers and mortality over time at 4 different water temperatures

to a lengthening of larval release over time at the population level. An extended larval release period spreads the risk of mortality across time; so the sponge does not risk losing the entire reproductive effort because of isolated, stochastic events (Ilan \& Loya 1990).

Larval release is triggered in many sponges by a photoperiod-based mechanism. For instance, Amano (1986) demonstrated that the onset of darkness of the preceding day is the stimulus triggering larval release in Halichondria panicea, whereas the stimulus for Callyspongia ramosa is sunrise the day before (Amano 1988). We induced larval release in Haliclona tubifera and Halichondria magniconulosa by strong illumination, after keeping ripe adults for variable times in darkness. The mechanisms by which the light cue is translated into larval release remain completely unknown. So far, no photoreceptor has been identified in either adult sponges or larvae. It is possible that light cues are not perceived by adults, but by larvae only. Larvae of Mycale americana have been observed swimming actively in the subectosomal spaces of adults for several hours before being released through oscula (authors unpubl. data). This has also been observed in other species (Lévi 1956, Fell 1989).

We failed to find a stimulus triggering larval release in Tedania ignis; larval release was not induced by manipulating light or temperature conditions. How-

\section{Halichondria magniconulosa}

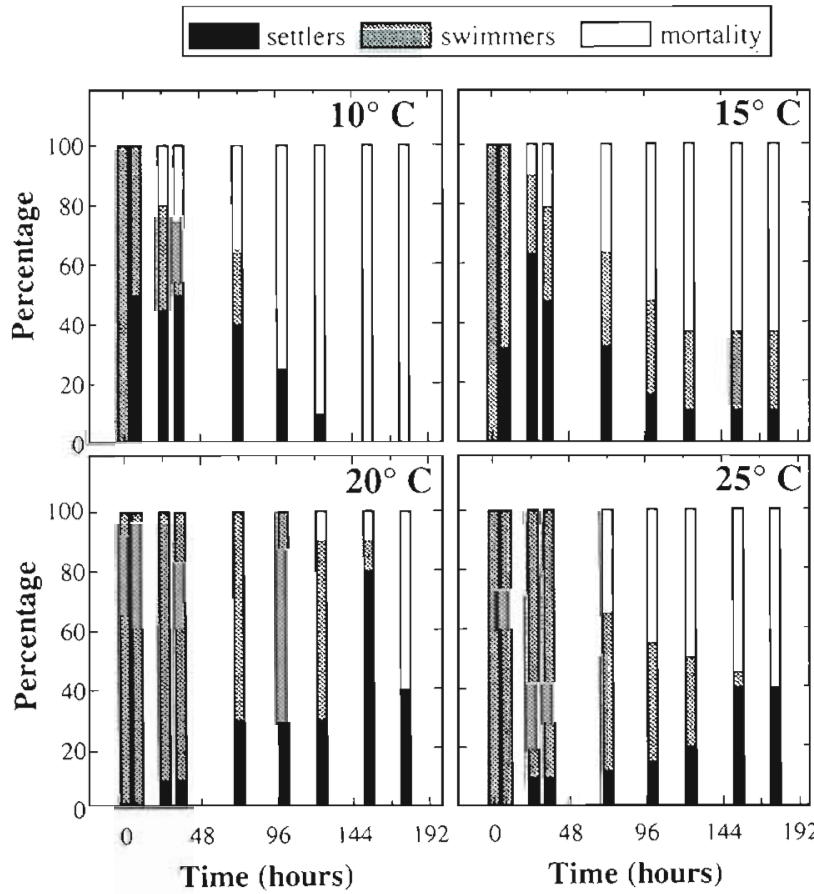

Fig. 9. Halichondria magniconulosa. Cumulative percentages of free-swimming larvae, settlers and mortality over time at 4 different water temperatures

ever, larvae were sometimes released spontaneously during the early morning hours of sunny days. Larval release was also apparently unrelated to lunar phases, which are known to control gametogenesis in some oviparous sponges (Hoppe \& Reichert 1987, Fromont \& Bergquist 1994).

In most demosponges, larvae are expelled through the oscula by the outgoing water effluent. Larvae of Tedania ignis leave the body of the parent by creeping through the ectosome. This is quite an exceptional pattern in demosponges, although a similar release pattern has been described in an unrelated species, Callyspongia diffusa (Sivaramakrishnan 1951).

The total number of larvae released per individual cannot be easily calculated. We have estimated that the mean density of embryos and larvae brooded $0.5 \mathrm{~cm}^{-2}$ is about 10.6 in Tedania ignis, 22.8 in Haliclona tubifera and 27.8 in Halichondria magniconulosa. Fell et al. (1987) reported an average of 205 embryos $\mathrm{cm}^{-2}$ in Haliclona loosanooffi and up to $343 \mathrm{~cm}^{-2}$ in an unidentified species of Halichondria. These values are about 5 times higher than the values for co-generic species in our study. Uriz (1982) reported an average of 6 larvae $\mathrm{cm}^{-2}$ in a species of a related genus, Hymeniacidon sanguinea. According to data from the literature, oviparous species show somewhat higher densities. For instance. Fromont \& 
Bergquist (1994) found values of about 93,156 , and 510 oocytes $0.5 \mathrm{~cm}^{-2}$ in 3 different species of the genus Xetospongia. It is also known that not all brooded larvae are actually released; some may be resorbed (Bergquist \& Sinclair 1968).

\section{Larval behavior}

Most sponge larvae, including those in this study, display a crawling behavior for a few minutes or hours just before settlement. This behavior is accompanied in some cases by extrusion of the anterior end of the larva. Although it appears that larvae are searching and testing surfaces, this point remains mere speculation because no tactile or chemical receptors are known in sponge larvae

Photoreceptors, which would explain the larval phototaxis, do not exist in parenchymella larvae either, or at least they have not yet been found. The posterior flagellar tuft of uniformly ciliated larvae, such as parenchymella larvae of demosponges, has traditionally been thought to provide maneuverabulity (Konstantinova 1966, Chia et al. 1983), but the flagellar tuft may also control swimming speed (Woollacott 1993). It has also been suggested that cells forming the posterior tuft are involved in photoreception (Woollacott 1993). The strong association between the larval swimming speed when moving away from a source of light and the ratio of larval body: flagellar tuft length suggests that the posterior tuft is highly involved in phototaxis either as receptor, an effector, or both. Posterior flagellar cells contain large granules apparently filled with pigment. A similar structure consisting of pigment granules and a paraflagellar swelling associated with a flagellum is responsible for the photoresponses of the protozoan Euglena (Wolken 1971). The pigment and associated organelles function as the photoreceptor and the flagellum functions as the effector. However, in Euglena, microfibrils connect the pigment granules and the flagellum, and such microfibrils have not been found in sponges. The bundless of microtubules forming the flagellar roots, which are present in all invertebrates, have not been found in parenchymella larvae either (Nielsen 1987), although they are described in the larva of the calcareous sponge Ascandra falcata (Borojevic 1969). Further ultrastructural studies are needed to understand the cytological basis of the larval photoresponse.

\section{Settlement and recruitment}

Parenchymella larvae usually attach by the anterior end. Nevertheless, we have observed attachment of Halichondria magniconulosa larvae by a lateral sur- face, corroborating previous reports of this particular feature in other species of this genus (Wilson 1935, Wapstra \& van Soest 1987) and in the related genus Hymeniacidon (Uriz 1982)

In experimental conditions, the presence of $3 \mathrm{~cm} \mathrm{~s}^{-1}$ flow had no effect on the success of larval settlement. The boundary shear stress at this flow rate did not prevent larvae from attaching to the smooth glass surfaces, despite the fact that larvae could not swim upstream. Furthermore, larvae of all 4 species significantly preferred shaded sites at settlement. This result suggests that, despite the possible existence of a passive transport by near-bottom flows, the active larval response to light is still important in determining the small-scale spatial distribution at settlement. However, larval responses in nature may differ from the laboratory responses as, apart from flow regimes, many other environmental factors can affect the larval choice at settlement (substratum characteristics, chenical cues, pycnoclines occurrence, turbidity, etc)

Light conditions in the natural microhabitats were not significantly related to the adult abundance of 3 species; the only exception was Sigmadocia caerulea. After $96 \mathrm{~d}$, recruitment and adult abundances of Tedania ignis and Haliclona tubifera respectively were associated with the current regimen. This suggests that although the presence of water current does not affect larval choice for settlement, it can influence the post-larval survivorship of some species. High light intensities have been demonstrated to kill some sponges (Jokiel 1980). However, it is also true that many shallow-water Caribbean demosponges grow in sites with strong light (de Laubenfels 1950). Some of our observations suggest that post-settlement mortality is not affected by the presence of light itself, but by associated factors. For example, juvenile sponges growing on horizontal surfaces are highly exposed to light, but they are also highly exposed to siltation and algal overgrowth, both factors known to have negative effects on sponge survival (Sará \& Vacelet 1973, Wilkinson \& Vacelet 1979, Zea 1992, 1993). Although many adult sponges in our study sites were clearly exposed to light, it is possible that their original settlement sites may actually have been located in small crevices or holes where early juveniles were protected from siltation and algae. It seems, therefore, that although light is used by larvae as a major cue for orientation and selection of settlement sites, light provides only an indirect cue for sites where the survivorship may be enhanced.

Survival of Tedania ignis and Sigmadocia caerulea was much higher than that of Haliclona tubifera and Halichondria magniconulosa after $8 \mathrm{~d}$ in standard laboratory conditions. Mortality in laboratory conditions was virtually zero in the first 2 species, while it was 
about 40 to $50 \%$ in the latter two (Fig. 5). The major sources of mortality in the laboratory were bacterial infections and predation by ciliates. Although laboratory mortality and its sources are not necessarily related to those operating in natural conditions, it is clear that larvae of $S$. caerulea and $T$. ignis larvae are generally less susceptible to mortality than the other species. Recruitment on experimental surfaces placed in the natural community indicates that the 2 species that survived well in the laboratory also recruit better in the field. This could explain the higher adult abundances of these 2 species in many shallow-water Caribbean assemblages (e.g. Hetchel 1965, Zea 1987).

Water temperature controls the duration of the different behavioral phases of larval life. At 10 and $15^{\circ} \mathrm{C}$, swimming speed decreased, the free-swimming phase was dramatically shortened, and metamorphosis was inhibited. Low temperatures, therefore, potentially prevent larval dispersal and recruitment into cold waters and might restrict the distribution of Haliclona tubifera and Halichondria magniconulosa to tropical areas and warm shallow waters. Sharp temperature changes also resulted in lengthening and shortening of the larval body in $H$. magniconulosa. This body reshaping could result from flattening and 're-shaping' processes of the high, cuboidal epithelial cells.

Acknowledgements. We are indebted to Isabel Vaquerizo for her help in both field and laboratory work and Dr Anna Metaxas for critical review of this manuscript. We thank 3 anonymous reviewers for their valuable comments. This study was supported by a postdoctoral Fulbright-MEC grant (FU9302207057) to M.M. This is Harbor Branch contribution number 1126

\section{LITERATURE CITED}

Amano S (1986) Larval release in response to a light signal by the intertidal sponge Halichondria panicea. Biol Bull 171: $371-378$

Amano S (1988) Morning release of larvae controlled by the light in an intertidal sponge, Callyspongia ramosa. Biol Bull 175:181-184

Bavastrello G, Bonito M, Sará M (1993) Influence of depth on the size of sponge spicules. Sci Mar 57(4): 415-420

Bergquist PR, Sinclair ME (1968) The morphology and behaviour of larvae of some intertidal sponges. NZ J Mar Freshwat Res 2:426-437

Bergquist PR, Sinclair ME (1973) Seasonal variation in settlement and spiculation of sponge larvae. Mar Biol 20:35-44

Bergquist PR, Sinclair ME, Hogg JJ (1970) Adaptation to intertidal existence: reproductive cycles and larval behaviour in Demospongiae. Symp Zool Soc Lond 25:247-271

Borojevic R (1969) Étude de développement et de la différenciation celullaire d'éponges calcaires calcinéennes (genre Clathrina et Ascandra). Ann Embryol Morphog Fr 2:15-36

Butman CA (1987) Larval settlement of soft-sediment invertebrates: spatial scales of pattern explained by active habitat selection and the emerging role of the hydrodynamical processes. Oceanogr Mar Biol A Rev 25:113-165
Chia FS, Buckland-Nicks J, Young CM (1983) Locomotion of marine invertebrate larvae: a review. Can $J$ Zool 62 : $1205-1222$

de Laubenfels MW (1950) An ecological discussion of the sponges of Bermuda. Trans Zool Soc Lond 27:155-201

Denny MW (1988) Biology and the mechanics of the waveswept environment. Princeton University Press, Princeton, NJ

Dolmer P, Svane I (1993) Settlement patterns of the scyphozoan Cyanea capillata (L.) planula: effects of established scyphistomae and water flow. Ophelia 38:117-126

Fell PE (1974) Porifera. In: Giese AC, Pearse JS (eds) Acoelomate and pseudocoelomate metazoans. Academic Press, New York, p 51-132

Fell PE (1989) Porifera. In: Adiyodi KG, Adiyodi RG (eds) Reproductive biology of invertebrates, Vol IV, Part A, Fertilization, development and parental care. John Wiley \& Sons, New York, p 1-41

Fromont J (1988) Aspects of the reproductive biology of Xestospongia testudinaria (Great Barrier Reef). Proc 6th Int Coral Reef Symp 2:685-691

Fromont J, Bergquist PR (1994) Repoductive biology of three sponge species of the genus Xetospongia (Porifera: Demospongiae: Petrosida) from the Great Barrier Reef. Coral Reefs 13:119-126

Fry WG (1971) The biology of larvae of Ophlitaspongia seriata from two North Wales populations. In: Crisp DJ (ed) 4th Eur Mar Biol Symp. Cambridge University Press, London, p $155-178$

Hartman WD (1958) Natural history of the marine sponges of Southern New England. Bull Peabody Mus Nat Hist 12 $1-155$

Hays WL (1963) Statistics. Holt, Rinehart \& Winston, Inc., New York

Hentschel E (1929) Die Kiesel- und Hornschwämme des Nördlichen Meeres. Fauna Artc 5:859-1042

Hetchel GJ (1965) A systematic study of the Demospongiae of Port Royal, Jamaica. Bull Peabody Mus Nat Hist 20: $1-103$

Hoppe WF (1988) Reproductive patterns in three species of large coral reefs sponges. Coral Reefs 7:45-50

Hoppe WF, Reichert MJM (1987) Predictable annual mass release of gametes by the coral reef sponge Neofibularia nolitangere (Porifera: Demospongiae). Mar Biol 94: $277-285$

Hulburt CJ (1993) The adaptive value of larval behavior of a colonial ascidian. Mar Biol 115:253-262

Ilan M, Loya Y (1988) Reproduction and settlement of the coral reef sponge Niphates sp. (Red Sea). Proc 6th Int Coral Reef Symp 2:745-749

llan M, Loya X (1990) Sexual reproduction and settlement of the coral reef sponge Chalinula sp. from the Red Sea. Mar Biol 105:25-31

Jokiel PL (1980) Solar ultraviolet radiation and coral reef epifauna. Science 207:1069-1071

Keough MJ, Downes BJ (1982) Recruitment of marine invertebrates: the role of active larval choices and early mortality. Oecologia 54:348-352

Konstantinova MI (1966) Characteristics of movement of pelagic larvae of marine invertebrates. Dokl Akad Nauk SSSR 170:726-729

Lévi C (1956) Etude des Halisarca de Roscoff. Embryologie et systématique des Demosponges. Archs Zool Exp Gén 93: $1-181$

Ludwig JA, Reynolds JF (1988) Statistical ecology. A primer on methods and computing. John Wiley \& Sons, New York Nielsen C (1987) Structure and function of metazoan ciliary 
bands and their phylogenetic significance. Acta Zool 68 : 205-262

Pawlik JR (1992) Chemical ecology of the settlement of benthic marine invertebrates. Oceanogr Mar Biol A Rev 30 $273-335$

Pawlik JR, Butman CA (1993) Settlement of a marine tube worm as a function of current velocity: interacting effects of hydrodynamics and behavior Limnol Oceanogr 38 : $1730-1740$

Reid REH (1968) Bathymetric distributions of Calcarea and Hexactinellida in the present and the past. Geol Mag 105 : 546-559

Reiswig HM (1970) Porifera: sudden sperm release by tropical Demospongiae. Science 170:538-539

Reiswig HM (1973) Population dynamics of three Jamaican Demospongiae. Bull Mar Sci 23:191-226

Reiswig HM (1976) Natural gamete release and oviparity in Caribbean Demospongiae. In: Harrison FW, Cowden RR (eds) Aspects of sponge biology. Academic Press, Inc., New York, p 99-112

Sarà M (1961) Ricerche sul gonocorismo ed ermafroditismo nei Poriferi. Boll Zool 28:47-59

Sarà M, Vacelet J (1973) Ecologie des Démosponges. In: Grassé PP (ed) Spongiaires. Anatomie, physiologie, systématique, écologie. Masson et Cie, Paris, p 462-576

Simpson TL (1978) The biology of the marine sponge Microciona prolifera (Ellis \& Solander). III. Spicule secretion and the effect of temperature on spicule size. $J$ Exp Mar Biol Ecol 35:31-42

Siribelli L (1962) Differenze nel ciclo sessuale di popolazioni conviventi di Axinella damicornis (Esper) ed Axinella verruvosa $\mathrm{O}$. S. (Demospongiae). Annu Ist Mus Zool Univ Napoli 14:1-7

Sivaramakrishnan VR (1951) Studies on early development and regeneration in some Indian sponges. Proc Indian Acad Sci 34B:213-310

Snelgrove PVR (1994) Hydrodynamic enhancement of invertebrate larval settlement in microdepositional environments: colonization tray experiments in a muddy habitat. J Exp Mar Biol Ecol 176:149-166

Sokal RR, Rohlf FJ (1981) Biometry. Freeman WH, San FranCisco

Uriz MJ (1982) Reproducción en Hymeniacidon sanguinea (Grant, 1926): biología de la larva primeros estadios postlarvarios. Invest Pesq 46:29-39

Vacelet J (1988) Indications de profondeur donnés par les Spongiaires dans les milieux benthiques actuels. Géol

This article was presented by J. Pawlik, Wilmington,

North Carolina, USA
Méditerr 15:13-26

Wapstra M, van Soest RWM (1987) Sexual reproduction, larval morphology and behaviour in Demosponges from the southwest of the Netherlands. In: Vacelet J, Boury-Esnault $N$ (eds) Taxonomy of Porifera. Springer Verlag, Berlin, p 281-307

Warburton FE (1966) The behavior of sponge larvae. Ecology $47: 672-674$

Warner GF (1977) On the shapes of passive suspension feeders. In: Keegan BF, Ceidigh PO, Boaden JJS (eds) Biology of benthic organisms. Pergamon Press, New York, p $567-576$

Wilkinson CR, Vacelet J (1979) Transplantation of marine sponges to different conditions of light and current. J Exp Mar Biol Ecol 37:91-104

Wilson $H$ van $P$ (1935) Some critical points in the metamorphosis of the halichondrine sponge larva. J Morph 58: $285-353$

Witte U, Barthel D, Tendal O (1994) The reproductive cycle of the sponge Halichondria panicea Pallas (1766) and its relationship to temperature and salinity. J Exp Mar Biol Ecol 183:41-52

Wolken JJ (1971) Invertebrate photoreceptors. A comparative study. Academic Press, New York

Woodin SA (1986) Settlement of infauna: larval choice? Bull Mar Sci 39:401-407

Woollacott R (1990) Structure and swimming behavior of the larva of Halichondria melanodocia (Porifera: Demospor1giae). J Morph 205:135-145

Woollacott R (1993) Structure and swimming behavior of the larva of Haliclona tubifera (Porifera: Demospongiae). J Morph 218:301-321

Young CM, Braithwaite LF (1980) Orientation and currentinduced flow in the stalked ascidian Styela montereyensis. Biol Bull 159:428-440

Young CM, Chia FS (1984) Microhabitat-associated variability in survival and growth of subtidal solitary ascidians during the first 21 days after settlement. Mar Biol 81:61-68

Zea S (1987) Esponjas del Caribe colombiano. Editorial Catálogo Científico, Santa Marta

Zea S (1992) Estimation of demosponge (Porifera, Demospongiae) larval settlement rates from short-term recruitment rates: preliminary experiments. Helgol Meeresunters 46 293-300

Zea S (1993) Cover of sponges and other sessile organisms in rocky and coral reef habitats of Santa Marta, Colombia Caribbean Sea. Caribb J Sci 29:75-88

Manuscript first received: December 4, 1995

Revised version accepted: February 15, 1996 